\title{
Evolution during the productive life and individual variability of milk emission at machine milking in Sardinian $\times$ Lacaune back-cross ewes
}

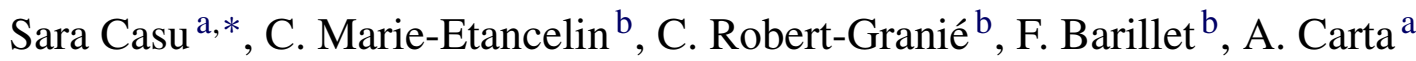 \\ ${ }^{a}$ Istituto Zootecnico e Caseario per la Sardegna, SS Sassari-Fertilia km 18.6, \\ 07040 Olmedo, Italy \\ b Station d'Amélioration Génétique des Animaux, Institut National de la Recherche Agronomique, \\ BP 52 627, 31326 Castanet-Tolosan Cedex, France
}

Received 19 June 2007; accepted 5 July 2007

Available online 5 September 2007

\begin{abstract}
Breeders have always been interested in improving the ewes' milkability, since the milking is the most time-consuming task of dairy sheep farmers. This work was aimed at studying the evolution during the productive life and the individual variability of milk emission traits at machine milking in sheep. Data were recorded in an experimental flock of 889 Sardinian $\times$ Lacaune back-cross ewes, by using an automatic device developed by INRA. The analyzed variables (59,615 records) were total milk yield (TMY, ml), machine milk yield (MMY, ml), stripped milk yield (SMY, ml), machine milking time (MMT, s), latency time (LT, s), maximum (MMF) and average (AMF) milk flow (ml/s), collected fortnightly at a.m. and p.m. milking for 4 years. Univariate mixed models were used for estimating the evolution of traits with lactation stage and parity number and the relative weights of sire and individual variances within date and lactation and across lactations.

As general trend, MMY and SMY decreased with lactation stage. SMY and its ratio with TMY increased from first to fourth parity. TL increased and MMF and AMF decreased with lactation stage and parity number. Machine milking time decreased with lactation stage and increased in adult ewes less than proportionally to the variation in machine milk yield. Most of milkability traits were highly repeatable within date. Within lactation repeatability was high for MMY, MMF and LT and moderate for TMY, SMY and AMF. Similar within date, within lactation and across lactations repeatability estimates for MMF and LT suggest that these traits are affected by random sources of variation, both environmental and genetic, which are constant in time. The proportion of the sire variance respect to the overall phenotypic variance ranged from $4 \%$ for MMT to $27 \%$ for MMF. These proportions were particularly high for MMY, LT, AMF and MMF and low for SMY and MMT. All the milk emission traits were favorably correlated between them and with milk yield. Only SMY showed low individual correlation with the other traits. Results suggest that milk emission traits are genetically determined and can be improved through selection. LT and MMF are the most relevant measurements to characterize the ewes' machine milking speed due to the high repeatability and the favorable correlation with MMT.
\end{abstract}

(C) 2007 Elsevier B.V. All rights reserved.

Keywords: Dairy sheep; Machine milking ability; Milking speed

\footnotetext{
* Corresponding author at: Settore Genetica Applicata alle Produzioni Animali, Istituto Zootecnico e Caseario per la Sardegna, Loc. Bonassai, SS Sassari-Fertilia km 18.6, 07040 Olmedo (SS), Italy. Tel.: +39 079 387313; fax: +39 079389450.

E-mail address: saracasu@tiscali.it (S. Casu).
} 


\section{Introduction}

Machine milking is the most time-consuming and laborious task of dairy sheep farmers. The ability of the personnel, the technical characteristics of the machine and the milking parlour affect the efficiency in terms of number of ewes milked by an operator per time unit. The time devoted to this task is also related to the single ewe's milkability. For small ruminants, which are generally milked in group, homogeneity in milkability of the whole flock is also essential. Indeed, the presence of a single animal needing long time to be milked slackens the working rate and extents the whole milking duration.

Machine milkability is the capacity of a dairy ewe to allow the machine extracting quickly and completely the milk from the udder with few manual interventions. Completeness of udder empting depends on both physiological and anatomical features. Between two successive milkings, a portion of milk is discharged into the cistern whereas a certain amount still remains in the alveoli and the small galactophores at the top of the udder. During the milking, the alveolar milk, which is the richest in fat (Labussière, 1969; McKusic et al., 2002), can be ejected only after the contraction of the myoepithelial muscle cells surrounding the alveoli. This process is mediated by the oxytocin, a pituitary hormone released into the blood after a neuro-humoral reflex (Labussière et al., 1969; Bruckmaier et al., 1997) induced by external stimuli (the start of the milking or suckling but also the sight of the lamb or the usual milker and the sound of the vacuum pump). The complete extraction of the cisternal milk is mainly related to udder morphology (Labussière, 1988). In fact, a variable amount of cisternal milk can be kept below the teats in the mammary gland pocket (Bruckmaier and Blum, 1992; Bruckmaier et al., 1997) and needs manual interventions of the milker to be extracted (stripping, i.e. the massage of the udder with the clusters still attached). Thus, udder morphology traits, in particular teat position and udder height, determine the need of stripping and the relative amount of milk (Casu et al., 1983, 2000). Appraisal methods of udder morphology enabling large scale phenotype recording have been developed during the last decade (de la Fuente et al., 1996; MarieEtancelin et al., 2001). Udder traits show moderate to high heritability (Fernandez et al., 1997; Serrano et al., 2002; Legarra and Ugarte, 2005; Marie-Etancelin et al., 2005; Casu et al., 2006) and have been taken into account in several dairy sheep breeding programs (Legarra and Ugarte, 2005; Casu et al., 2006; Barillet, 2007).
On the other hand, individual milking speed depends on the capacity of the ewe to express and maintain high milk emission flows. As demonstrated in dairy cattle (Le Du et al., 1994; Weiss et al., 2004) and suggested both in dairy goat (Le Du and Benmederbel, 1984) and sheep (Marnet et al., 1999), milk emission flows depend on anatomical and functional characteristics of the teat such as the canal length and diameter or the sphincter tightness and elasticity.

In both dairy cattle and goat the genetic variability of milking speed, measured by different criteria, has been demonstrated. In cattle milkability is taken into account as selection objective in several breeding programs (Sprengel et al., 2001; Santus and Ghiroldi, 2005). In goat, there is evidence of a major gene affecting the speed of the first minute milk emission (Ricordeau et al., 1990; Ilahi et al., 2000) but no selection for this trait has been implemented yet. In sheep, few studies on the genetic determinism of milking speed have been carried out (Marie-Etancelin et al., 2006; Casu, 2004) due to the laboriousness of large scale recording. In the nineties, INRA developed an electronic jar for milk recording of small ruminants (European patent no. 94916284.6) which is able to register the kinetics of milk emission of a single ewe during the collective milking. Before possibly extending the use of such electronic meters in the selection nucleus flocks, INRA electronic jars have been tested in experimental flocks in France (Marie-Etancelin et al., 2002, 2006) and Italy (Carta et al., 2000; Marie-Etancelin et al., 2001, 2003). In particular, they have been used in a backcross Sardinian $\times$ Lacaune population procreated in the framework of an EU funded project ("Genesheepsafety", Barillet et al., 2006), aimed at detecting chromosomal regions (QTL) which affect traits of economic importance in sheep.

This paper presents the results of a study aimed at evaluating the evolution during the productive life and the individual variability of milk emission traits recorded in the Sardinian $\times$ Lacaune population using INRA electronic jars. Estimation of individual variance as well as repeatability of the traits within and across lactations are presented.

\section{Materials and methods}

\subsection{Experimental population}

The 967 ewes of the Sardinian $\times$ Lacaune back-cross population were born between December 1998 and January 1999 from 10 F1 Lacaune $\times$ Sardinian sires and 2719 Sardinian ewes. They were bred in an experimental farm located in the South of Sardinia. The feeding regimen was based on $4-5 \mathrm{~h}$ 
of grazing irrigated mixed swards of ryegrass and berseem clover with important supplementations of alpha-alpha hay, maize silage and concentrates particularly in winter and late spring. First lambings occurred between January and March 2000 whereas further lambings occurred between November and December in 2000, 2001 and 2002. Neither voluntary culling nor selection was applied to the experimental population before 2004. Thus the back-cross ewes, except those which died by natural causes, performed 4 lactations before being slaughtered. Every year, after 20-30 days of suckling, ewes were milked twice a day (at approximately 5.00 a.m. and 3.30 p.m.) until July when they were progressively dried off and milked only at morning.

\subsection{Milking installation and milk yield recording device}

The milking installation was a $24 \times 2$ stalls milking parlour with high-level pipeline and 12 milking units. Milking was conducted with pressure vacuum of $44 \mathrm{kPa}$, pulsation rate of $120 \mathrm{pulses} / \mathrm{min}$ and $50 \%$ pulsation ratio. The automatic milk recording system consists of 12 electronic jars (Guillouet et al., 1990; Ricard et al., 1994). Each jar is equipped with electronic sensors able to follow and record the milk that is progressively collected during the milking. Each jar, of 2.91 volume, has a $160 \mathrm{ml}$ bottom space which has to be filled to allow the starting of milk yield recording. The time needed to fill this space (latency time, LT, s) is recorded. Twelve measures of cumulated milk yield $\left(\mathrm{MY}_{i}, i=1-12\right)$ can be stored for each milked ewe. The intermediate measures are taken at constant lag, which can be fixed for each collective milking. Only the first measurement of milk yield $\left(\mathrm{MY}_{1}\right)$ is recorded at an interval from the teat cup attachment $\left(\mathrm{T}_{1}, \mathrm{~s}\right)$ which is variable. Actually, $\mathrm{MY}_{1}$ is recorded after the first $160 \mathrm{ml}$ of milk have been collected, at a time that is a multiple of the chosen lag $\left(T_{1}=n \times \mathrm{lag}\right)$. For example, setting a $8 \mathrm{~s}$ lag, if the first $160 \mathrm{ml}$ of milk are collected in $13 \mathrm{~s}(\mathrm{LT}=13 \mathrm{~s}) \mathrm{MY}_{1}$ is recorded at $T_{1}=2 \times 8=16 \mathrm{~s}$, that is the first multiple of the lag after LT. The INRA device finally provides the measure of total milk yield (TMY, ml) and the time of teat-cups attachment (Fig. 1).

\subsection{Data collection and traits definition}

From 2000 to 2003, milk yield and milk emission traits were measured fortnightly, at the morning and afternoon milkings. Lag between intermediate measures was $8 \mathrm{~s}$ except for the last part of the first lactation when it was set at $6 \mathrm{~s}$. Indeed, at that period a $6 \mathrm{~s}$ lag was sufficient to allow the end of machine milk emission before the 12th measure for most of milkings. No manual intervention was done before the last (12th) intermediate measurement, and machine stripping started only after this measure had been recorded. A total of 83,018 individual milkings were recorded. For each individual milking, 11 milk emission flows $(\mathrm{ml} / \mathrm{s})$ were calculated as the ratio between the milk collected between two successive measures and the lag. The initial milk emission flow was calculated as the ratio between $\mathrm{MY}_{1}$ and $T_{1}$.

Machine milkability was studied through the following elementary traits:

- Machine milk yield (MMY, ml), that is the amount of milk extracted by the milking machine with no manual intervention. This amount is equal to $\mathrm{MY}_{12}$, but can be collected before the 12th measurement.

- Machine milking time (MMT, s), that is the time of the first intermediate measure in which MMY is recorded.

- Stripped milk yield (SMY, ml), that is the amount of milk extracted by massing the udder after the 12th measurement and before the clusters removal (SMY $=\mathrm{TMY}-\mathrm{MMY})$.

- Average milk flow (AMF, $\mathrm{ml} / \mathrm{s}$ ), that is the ratio between MMY and MMT.

- Maximum milk flow (MMF, ml/s), that is the maximum among the 12 calculated milk flows.

The duration of teat-cups attachment was not retained as a criterion for evaluating milking time because it is determined by the collective routine of milking rather than by the individual milkability. Abnormal data, i.e. from milkings with teat-cup falls, or presenting $\mathrm{LT}<2 \mathrm{~s}$ or $>90 \mathrm{~s}$ or $\mathrm{MMF}>200 \mathrm{ml} / \mathrm{s}$, were discarded ( $22 \%$ of recorded data). Furthermore only ewes having performed the first lactation in 2000 and with at least

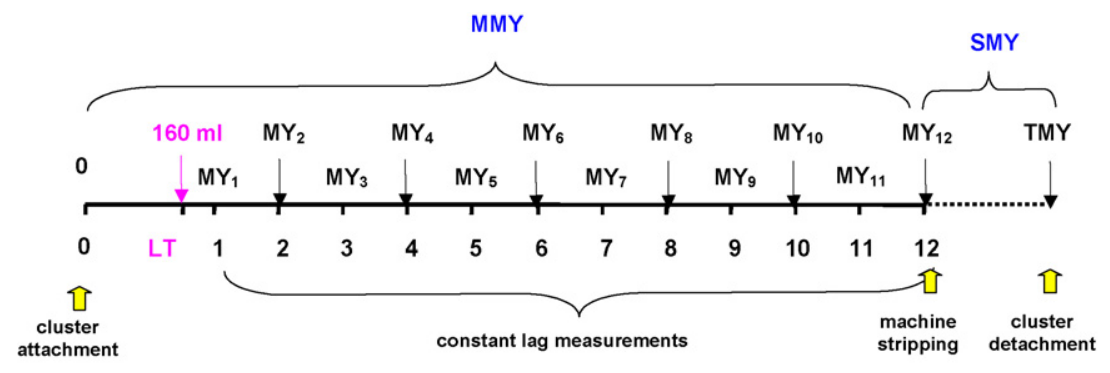

MYi, i=1 to 12: intermediate measure of milk yield; LT: latency time; MMY: machine milk yield;

SMY: stripped milk yield; TMY: total milk yield;

Fig. 1. Schematic representation of milk emission data recording with the INRA automatic device. 
three correctly recorded kinetics were retained (discarding further 5122 records of 43 animals). Finally, the edited dataset included 59,615 individual milkings from 889 ewes recorded in 55 test-dates.

\subsection{Statistical models}

The statistical models of analysis included as main environmental factors the parity number (four levels), the lactation stage (six 30 days intervals in first lactation and seven in later parities), the moment of milking (morning or afternoon), the litter size (one lamb or more) and the milker (four operators). The level of udder filling was also considered to take into account intra-mammary pressure which can modify milk emission speed. Indeed a high level of intra-mammary pressure may result in high milk flow rate and large amount of MMY. The intra-mammary pressure depends either on the amount of milk in the udder at the moment of the milking or the ewe's udder volume. As a matter of fact the intramammary pressure may be low in large udders even with high milk yields. On the contrary, small udders may be submitted to high intra-mammary pressures even with low milk yields. The udder volume was estimated for each ewe-lactation as the maximum recorded milk yield $\left(\mathrm{MY}_{\max }\right)$. To adjust for the intra-mammary pressure the level of udder filling was calculated as the ratio between TMY at the considered milking and $\mathrm{MY}_{\max }$.

A linear mixed model was used for analyzing individual repeated records of milk emission traits. Fixed effects to include in the final model were selected by preliminary analyses, performed with a mixed model (Mixed procedure of SAS software SAS, 2000) which contained the ewe random effect.

The final model used to study the evolution of milk emission traits during the productive life and the individual variability of these traits was the following:

$$
\begin{aligned}
y_{i j k l m n o p q}= & \mu+\mathrm{PLM}_{i q}+O_{i q j}+\mathrm{NL}_{i q k}+b_{i} \mathrm{UF}+a_{m n} \\
& +\mathrm{ap}_{m n o}+\mathrm{ad}_{m n p}+s_{n}+\mathrm{sp}_{n o}+\mathrm{sd}_{n p}+e_{i j k l m n o p q}
\end{aligned}
$$

where $y_{i j k l m n o p q}$ is the performance (LT, SMY, MMY, MMT, AMF or MMF) of ewe $\mathrm{m}$ from sire $n, \mu$ the population mean, $\mathrm{PLM}_{i q}$ the fixed effect of the parity-lactation stage combination $i \times$ milking moment $q, O_{i q j}$ the fixed effect of the milker $j$ within parity-lactation stage-milking moment $i q, \mathrm{NL}_{i q k}$ the fixed effect of the number of lambs born $\mathrm{k}$ within parity-lactation stage-milking moment $i q$, UF is a covariate describing the level of udder filling at that considered milking (expressed as the deviation from the average level of udder filling of the parity-lactation stage combination $i$ ) and $b_{i}$ is the corresponding regression coefficient. The model for TMY did not include the regression on UF since TMY was used to calculate it.

For all traits $a_{m n}, \operatorname{ap}_{m n o}, \mathrm{ad}_{m n p}, s_{n}, \mathrm{sp}_{n o}, \mathrm{sd}_{n p}$ were the ewe, ewe within lactation, ewe within date and the sire, sire within lactation, sire within date random effects; $e_{\text {ijklmnopq }}$ was the random residual. All the random effects were consid-
Table 1

Descriptive statistics of milk emission traits

\begin{tabular}{lrrrr}
\hline Trait & Mean & \multicolumn{1}{c}{ S.D. } & Min & Max \\
\hline TMY (ml) & 797.5 & 262.6 & 280.0 & 2330.0 \\
MMY (ml) & 676.4 & 244.4 & 270.0 & 2030.0 \\
SMY (ml) & 121.2 & 92.8 & 0.0 & 1110.0 \\
MMT (s) & 86.5 & 17.6 & 12.0 & 176.0 \\
LT (s) & 12.7 & 6.4 & 2.0 & 90.0 \\
AMF (ml/s) & 8.0 & 2.8 & 1.6 & 40.6 \\
MMF (ml/s) & 19.7 & 8.0 & 5.0 & 95.0 \\
\hline
\end{tabular}

TMY: total milk yield; MMY: machine milk yield; SMY: stripped milk yield; MMT: machine milking time; LT: latency time; AMF: average milk flow; MMF: maximum milk flow.

ered independently and normally distributed with variances $\sigma_{\mathrm{a}}^{2}, \sigma_{\mathrm{ap}}^{2}, \sigma_{\mathrm{ad}}^{2}, \sigma_{\mathrm{s}}^{2}, \sigma_{\mathrm{sp}}^{2}, \sigma_{\mathrm{sd}}^{2}$ and $\sigma_{\mathrm{e}}^{2}$, respectively.

The evolution of the traits with the lactation stage and parity was studied by adding to the overall mean the average of the a.m. and p.m. PLM effect solutions and the averages of the related $\mathrm{O}$ and $\mathrm{NL}$ effects solutions.

The repeatability of the traits within date $\left(\mathrm{rp}_{1}\right)$, within lactation $\left(\mathrm{rp}_{2}\right)$ and across lactations $\left(\mathrm{rp}_{3}\right)$ were estimated as follows:

$$
\begin{aligned}
& \mathrm{rp}_{1}=\frac{\sigma_{\mathrm{a}}^{2}+\sigma_{\mathrm{ap}}^{2}+\sigma_{\mathrm{ad}}^{2}+\sigma_{\mathrm{s}}^{2}+\sigma_{\mathrm{sp}}^{2}+\sigma_{\mathrm{sd}}^{2}}{\sigma_{\mathrm{a}}^{2}+\sigma_{\mathrm{ap}}^{2}+\sigma_{\mathrm{ad}}^{2}+\sigma_{\mathrm{s}}^{2}+\sigma_{\mathrm{sp}}^{2}+\sigma_{\mathrm{sd}}^{2}+\sigma_{\mathrm{e}}^{2}} \\
& \mathrm{rp}_{2}=\frac{\sigma_{\mathrm{a}}^{2}+\sigma_{\mathrm{ap}}^{2}+\sigma_{\mathrm{s}}^{2}+\sigma_{\mathrm{sp}}^{2}}{\sigma_{\mathrm{a}}^{2}+\sigma_{\mathrm{ap}}^{2}+\sigma_{\mathrm{ad}}^{2}+\sigma_{\mathrm{s}}^{2}+\sigma_{\mathrm{sp}}^{2}+\sigma_{\mathrm{sd}}^{2}+\sigma_{\mathrm{e}}^{2}} \\
& \mathrm{rp}_{3}=\frac{\sigma_{\mathrm{a}}^{2}+\sigma_{\mathrm{s}}^{2}}{\sigma_{\mathrm{a}}^{2}+\sigma_{\mathrm{ap}}^{2}+\sigma_{\mathrm{ad}}^{2}+\sigma_{\mathrm{s}}^{2}+\sigma_{\mathrm{sp}}^{2}+\sigma_{\mathrm{sd}}^{2}+\sigma_{\mathrm{e}}^{2}}
\end{aligned}
$$

Finally, covariances between milk emission traits and with TMY were estimated with 28 bi-trait analyses including the same fixed effects as the univariate models. Only the random effect of the ewe was considered in order to estimate the time independent individual correlations between traits.

The REML method provided by the ASREML software (Gilmour et al., 2002) was applied for variance components estimation.

\section{Results and discussion}

\subsection{Descriptive analysis of milking traits}

Machine milk yield (MMY) was collected on average in approximately $86 \mathrm{~s}$ (Table 1) whereas the average time at the 12 th measure was $100 \pm 11 \mathrm{~s}$. When machine milk emission was ended before the 12 th measurement $(68 \%$ of milkings) average machine milking time (MMT) was $80 \pm 16 \mathrm{~s}$. In the remaining $32 \%$ of cases, where MMY corresponded to $\mathrm{MY}_{12}$, both MMY and MMT may be underestimated, because the machine milk emis- 
sion would have continued. The average ratio between machine and total milk yield was 0.85 , indicating that most of the milk yield was extracted without manual interventions of the milker. This ratio was similar to that registered in Sardinian ewes by Casu (1967) and higher than that reported by Labussière $(1983,1988)$ for several dairy sheep breeds.

The average value of stripped milk yield (SMY) was relatively low $(122 \mathrm{ml})$, and probably overestimated in $32 \%$ of not ended machine milkings, when additional milk might have been extracted without handlings.

Latency time (LT) represented approximately 13\% of MMT. It was similar to LT measured in Sardinian primiparous ewes (12 s; Carta et al., 2000) and lower than that registered in the INRA experimental flock of Lacaune ewes (29 s; Marie-Etancelin et al., 2006). Since LT is a measure specific of the INRA milk recording devise, no comparison with other studies can be done.

Both maximum (MMF) and average (AMF) milk flow means (Table 1) fell in the range of values reported in literature. Previous studies carried out with the same electronic device on Sardinian (Carta et al., 2000) and Lacaune (Marie-Etancelin et al., 2006) ewes showed average MMF of respectively 19.4 and $12.9 \mathrm{ml} / \mathrm{s}$. Using manual measurement systems, Casu (1967) reported average MMF close to $40 \mathrm{ml} / \mathrm{s}$ in Sardinian ewes. Such et al. (1999) found an average MMF value of $25.5 \mathrm{ml} / \mathrm{s}$ for the Lacaune breed, i.e. about 2 times more than the Lacaune measurements in the French experimental flock (Marie-Etancelin et al., 2006). In other studies average values of MMF ranged from 9 to $18 \mathrm{ml} / \mathrm{s}$ (Labussière and Ricordeau, 1970; Bruckmaier et al., 1997). Such variability illustrates that available results can be hardly considered representative of a given cross or breed, since they also depend on the used milking routine, milking machine and recording device.

The AMF average value was lower than that reported in Sardinian ewes (Carta et al., 2000). On the other hand, no direct comparison can be done with the Lacaune experimental flock, since French researchers considered only measurements of yield collected after LT and thus did not include in the estimation of AMF the flow corresponding to the emission of $\mathrm{MY}_{1}$. In fact, Marie-Etancelin et al. (2006) reported the mean of 11 intermediate milk flow measurements $(5.4 \mathrm{ml} / \mathrm{s})$.

As a whole, short LT and early occurrence of MMF indicate a rapid response of an animal to the stimulus of the milking. In our experiment the highest milk flows occurred in the first $30 \mathrm{~s}$ from the clusters attachment. This outcome, as well as MMF and AMF values, suggests that the Sardinian $\times$ Lacaune back-cross had good machine milkability when compared to previous studies on other populations.

\subsection{Evolution of the traits during the productive life}

As expected, the degree of udder filling significantly affected all milk emission traits. Indeed the estimates of the regressions coefficient were negative for LT and positive for all the other traits: the higher the intra-mammary pressure the higher the milk emission flows, the machine and stripped milk yield and the shorter the latency time.

Fig. 2 shows milk yield and milking traits with lactation stage by parity number. As general trend, TMY, MMY and SMY decreased with lactation stage. This pattern was less evident for MMY in first lactation probably because the decrease in the production capacity of young ewes, pointed out by the constant reduction of TMY, was counterbalanced by the development of the udder and the fact that they got progressively used to the machine. Decrease of TMY and MMY with lactation stage is consistent with results of Ricordeau et al. (1963), Casu (1967) and Gallego et al. (1983). Differences in TMY between lactations were low and this can be partly due to the confounding between the parity and the year of production effects.

SMY and its ratio with TMY noticeably increased from first to fourth parity. This was likely a consequence of the progressive deterioration of udder morphology, particularly evident in this flock in which no culling was performed for udder morphology defects before the end of the 4th lactation. Indeed, Casu et al. (2006) reported for the same flock a clear increase of cistern height and a progressive deterioration of the degree of udder suspension with the age of the ewes.

LT showed a slightly increasing trend with the lactation stage, except in 1st lactation. Marie-Etancelin et al. (2006) found a more marked increasing pattern in Lacaune ewes. This difference is probably due to the adjustment for the degree of udder filling rather than to the different analyzed genetic types. From 1 st to 4 th parity LT increased (from 11.5 to $14.3 \mathrm{~s}$ on average) in agreement with results of Marie-Etancelin et al. (2006). MMF and AMF showed a decreasing trend with lactation stage and parity number.

As a whole, milkability worsens with the lactation stage and number. Indeed, MMT decreased with lactation stage and increased with parity number less than proportionally to the variation of MMY. These results were in agreement with the phenotypic trends of milkability traits observed in the Lacaune ewes (MarieEtancelin et al., 2006). 

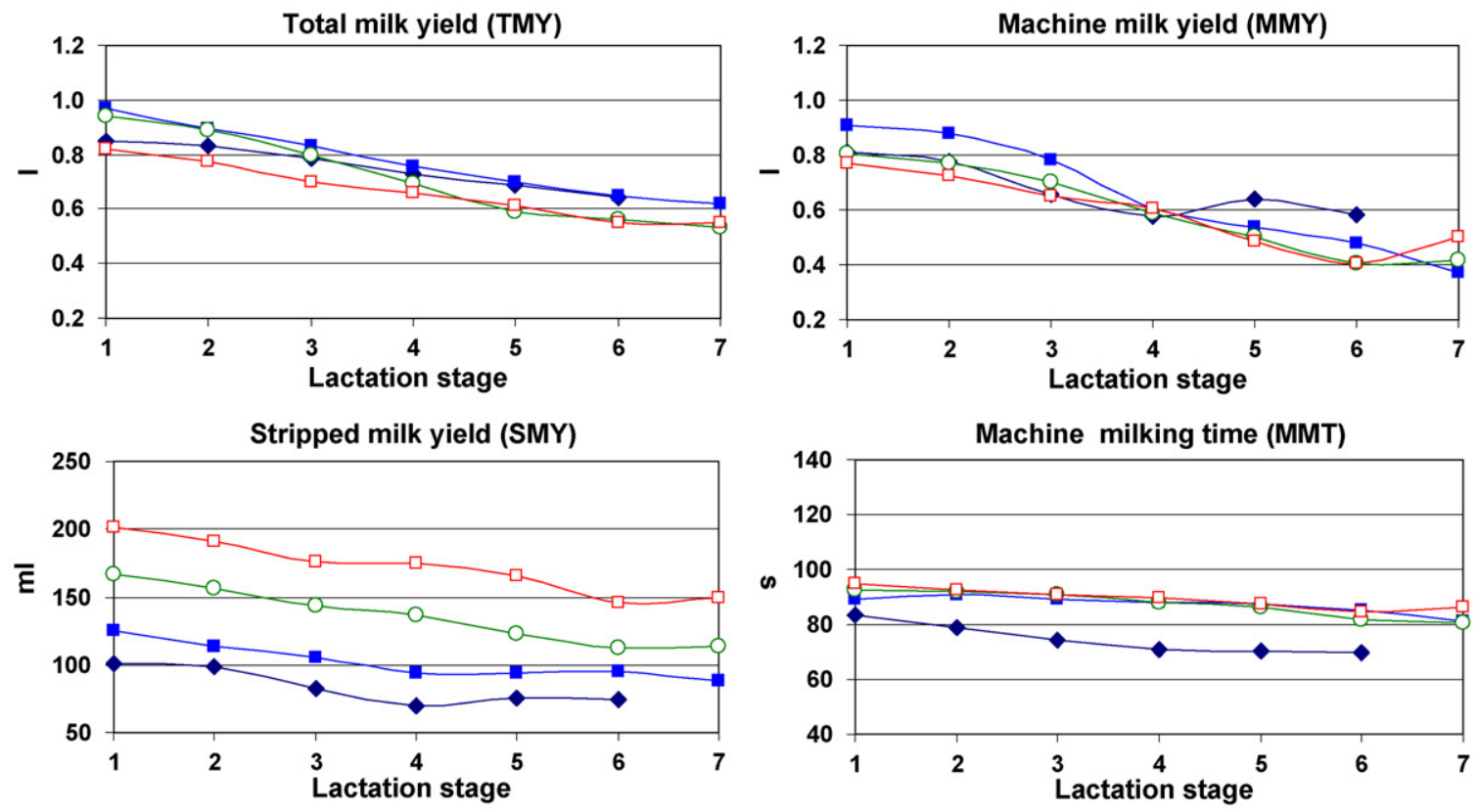

Latency time (LT)

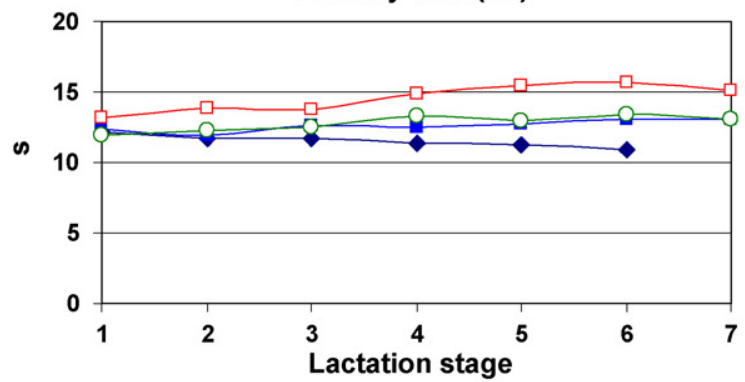

Average milk flow (AMF)
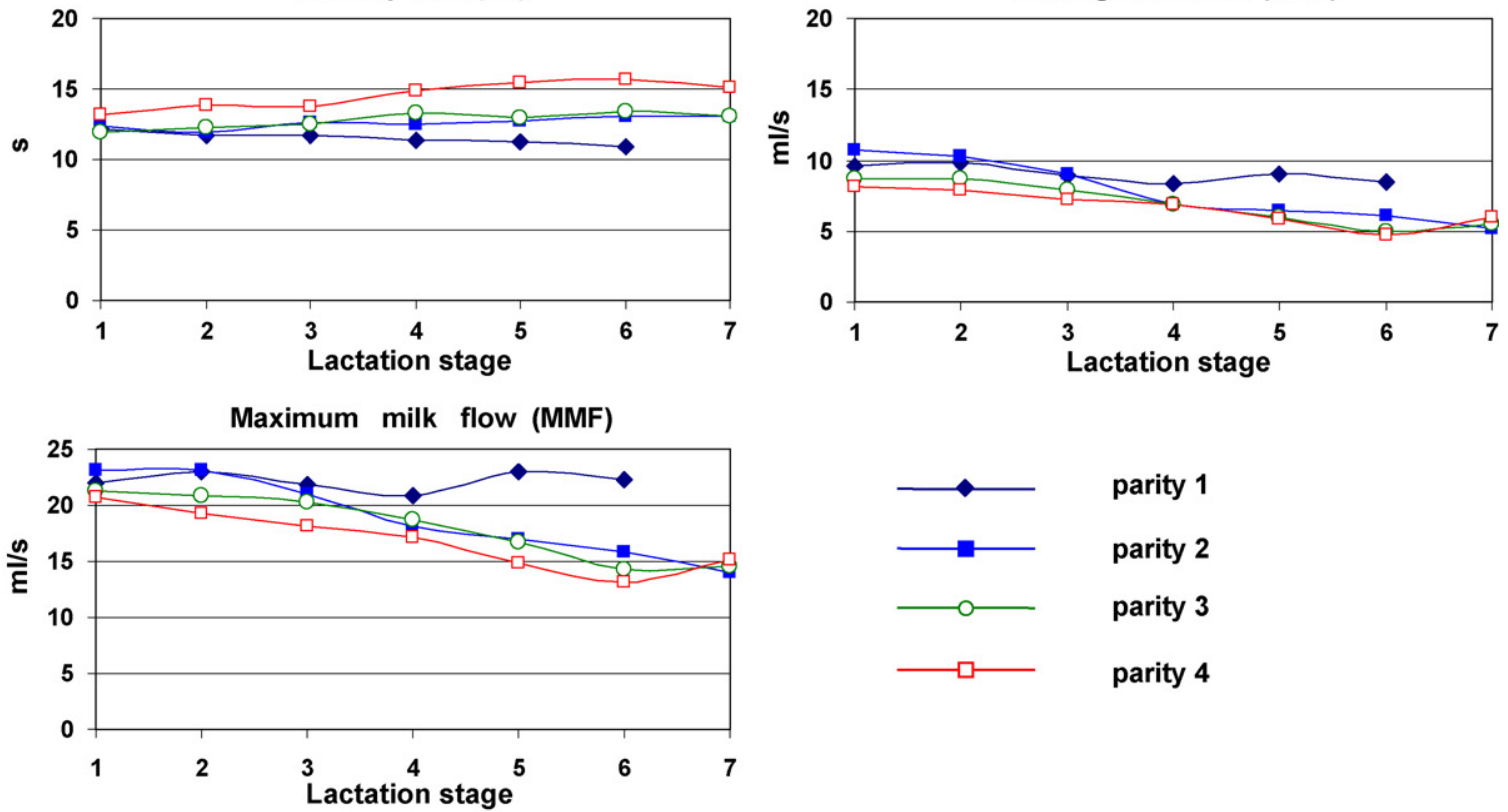

parity 1

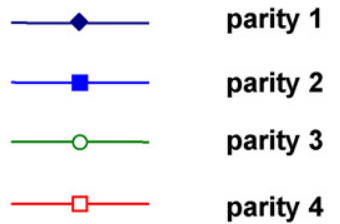

Fig. 2. Evolution of milk yield and milk emission traits with lactation stage (30 days interval classes) by parity number.

\subsection{Variance component and repeatability estimation}

Most of milkability traits were highly repeatable within date (Table 2). Estimated $\mathrm{rp}_{1}$ value was low only for MMT (0.32) and high for all others traits $(>0.62)$. Actually MMT was not exactly recorded in $32 \%$ of milkings for which the machine milk emission was not ended before the 12th automatic measure. Within lactation repeatability $\left(r p_{2}\right)$ was high for MMY, MMF and LT $(>0.70)$ and moderate for TMY, SMY and AMF (between 0.54 and 0.61). Even in this case, the lowest repeatability value was estimated for MMT (0.24). Finally, across lactation repeatability $\left(r p_{3}\right)$ was greater than 0.60 for LT and MMF, whereas the lowest values were estimated for TMY and MMT (0.36 and 0.20 


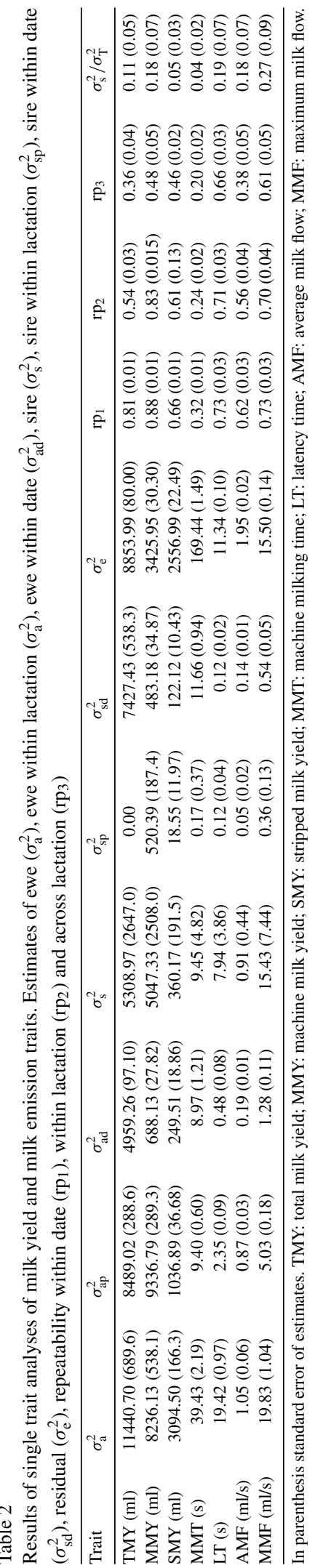

respectively). For MMF and LT estimated repeatability values were similar within date and lactation and across lactations. This result indicates that these traits are affected by both environmental and genetic sources of variation which are constant in time. This is true also if $\sigma_{\mathrm{s}}^{2}$ is considered, highlighting the prevalence of a time independent genetic component of the variability of these traits. This is in agreement with results of MarieEtancelin et al. (2002, 2006), who, by analyzing records from successive milk recordings as different traits, found that $h^{2}$ are stable within lactation and estimated a high genetic correlations between performances of the first and the following lactations $(>0.90)$.

On the contrary, genetic and environmental sources of variation are strongly time-dependent for the other traits, in particular TMY, MMY and AMF which showed relative low values of the individual and sire across lactations variance components respect to the overall individual variance.

The random sire effect was included in the model to provide an estimation of the genetic variance component. However, it has to be considered that this estimate is based on only 10 sires and could be inflated by other sources of covariation between daughters of a same sire. In fact, the experimental population (conceived for QTL detection purposes) was created by mating each $\mathrm{F} 1$ sire with ewes homogenous for age and flock of origin and each half-sib family was managed in the most possible homogeneous way. Notwithstanding, the comparison between the sire $\left(\sigma_{\mathrm{s}}^{2}, \sigma_{\mathrm{sp}}^{2}, \sigma_{\mathrm{sd}}^{2}\right)$ and the ewe $\left(\sigma_{\mathrm{a}}^{2}, \sigma_{\mathrm{ap}}^{2}, \sigma_{\mathrm{ad}}^{2}\right)$ variance component estimates (Table 2) allows drawing some inferences on the relative weights of additive genetic and permanent environmental variances. The proportion of the sire variance respect to the overall phenotypic variance ranged from $4 \%$ for MMT to $27 \%$ for MMF. These proportions were particularly high for MMY, LT, AMF and MMF. Heritability estimates based on $\sigma_{\mathrm{s}}^{2}$ for LT, AMF and MMF were higher than TMY, in agreement with results of Marie-Etancelin et al. (2006) in the Lacaune breed. The weight of $\sigma_{\mathrm{s}}^{2}$ respect to the overall phenotypic variance was low for SMY and MMT. As already reported by Flamant (1974), this outcome suggests that direct selection for these two traits in dairy sheep would be difficult.

\subsection{Correlations between traits}

Individual and total phenotypic correlations are presented in Table 3. As expected, TMY was highly correlated with MMY ( 0.89 and 0.90 for individual and phenotypic correlations respectively) but less correlated with SMY (0.40-0.34). TMY was favorably correlated 
Table 3

Correlations between milk emission traits: individual correlations above the diagonal, phenotypic correlations below the diagonal

\begin{tabular}{|c|c|c|c|c|c|c|c|}
\hline & TMY & MMY & SMY & MMT & $\mathrm{TL}$ & $\mathrm{AMF}$ & $\mathrm{MMF}$ \\
\hline TMY & & $0.89(0.007)$ & $0.40(0.029)$ & $0.23(0.033)$ & $-0.22(0.032)$ & $0.77(0.014)$ & $0.45(0.027)$ \\
\hline MMY & $0.90(0.003)$ & & $-0.01(0.030)$ & $0.15(0.034)$ & $-0.31(0.031)$ & $0.89(0.007)$ & $0.56(0.023)$ \\
\hline SMY & $0.34(0.014)$ & $-0.19(0.019)$ & & $0.14(0.034)$ & $0.03(0.034)$ & $-0.05(0.034)$ & $-0.05(0.034)$ \\
\hline MMT & $0.17(0.005)$ & $0.16(0.012)$ & $-0.07(0.012)$ & & $0.82(0.012)$ & $-0.30(0.032)$ & $-0.55(0.024)$ \\
\hline $\mathrm{TL}$ & $-0.18(0.018)$ & $-0.23(0.020)$ & $0.03(0.020)$ & $0.46(0.009)$ & & $-0.64(0.021)$ & $-0.80(0.012)$ \\
\hline $\mathrm{AMF}$ & $0.69(0.007)$ & 0.69 (0.007) & $-0.09(0.016)$ & $-0.53(0.009)$ & $-0.43(0.014)$ & & $0.81(0.012)$ \\
\hline $\mathrm{MMF}$ & $0.43(0.015)$ & $0.48(0.015)$ & $-0.09(0.019)$ & $-0.26(0.011)$ & $-0.60(0.012)$ & 0.59 (0.009) & \\
\hline
\end{tabular}

In parenthesis standard error of estimates. TMY: total milk yield; MMY: machine milk yield; SMY: stripped milk yield; MMT: machine milking time; LT: latency time; AMF: average milk flow; MMF: maximum milk flow.

with milk flow traits, in particular AMF (0.77 and 0.69) and MMF (0.45 and 0.43). Both individual $(-0.22)$ and total phenotypic $(-0.18)$ correlations between TMY and LT were low and negative. The individual correlation estimated between these two traits was similar to the genetic correlation estimated in the Lacaune breed (Marie-Etancelin et al., 2006). Both individual and phenotypic correlations between MMT and TMY or MMY were low. In a previous trial on Sardinian primiparous ewes, Carta et al. (2000) found a stronger individual correlation between MMY and MMT. However, in that trial machine milk emission was always completed when MMY was recorded, whereas in our case the machine stripping probably occurred before the end of the machine milk emission in $32 \%$ of cases. As a matter of fact MMT resulted more affected by milk emission flows rather than yields, as confirmed by the favorable individual and phenotypic correlations estimated with AMF (0.89 and 0.69) and MMF (0.36 and 0.48). Practically, the aptitude of high producing animals to show higher milk flows than the less productive ones seems compensating the negative effect of a high milk yield on the time needed to extract it. In agreement with this outcome Marie-Etancelin et al. (2006) showed that the Lacaune line selected for high milk yield had a significant higher milking speed than the divergently selected line.

Individual correlation between LT and MMT was high (0.82). Thus, ewes which respond quickly to the machine milking stimuli also tend to have high milk emission flows and short milking time.

Finally, all the milk emission traits were favorably correlated between them and with milk yield. Only SMY was not noticeable correlated with the other milk emission parameters. As previously observed by Marie et al. (1999) and Carta et al. (2000), this finding confirms that the milk emission speed concurs to define the machine milking ability of an ewe but does not determine the num- ber of manual interventions for stripping, which mainly depends on udder conformation.

\section{Conclusion}

This work showed that machine milkability of dairy ewes tends to worsen with the lactation stage and parity. As a whole, milk emission traits showed a quite important individual variability suggesting that they are genetically determined and can be improved through selection. Even if further research is needed to precisely estimate genetic parameters, latency time and maximum milk flow seem to be the most relevant measurements to characterize the ewes' machine milking speed. Indeed, they are highly repeatable within and across lactation and show favorable correlations with machine milking time. Selection for milk yield leads to a favorable correlated response on milk emission traits, as demonstrated by Marie-Etancelin et al. (2006). The increasing diffusion of automatic clusters detachment at a given time will strengthen the correlated genetic gain on milking speed when directly selecting only for milk yield. However, a direct selection for machine milking speed should be useful either to fasten the genetic improvement or to obtain animals more homogeneous in terms of machine milking duration. Anyway, the increased genetic progress expected from a direct selection on milk emission speed should be compared to the feasibility and the costs of an accurate large scale recording. Thus, the inclusion of milk emission speed in the selection objectives of dairy ewes lies either on the spreading of milk flow automatic recording devices approved by ICAR or on the detection of genes affecting milk emission traits. The latter could be used to plan gene-assisted selection in breeding schemes based on a small number of recorded phenotypes. In this view, results of QTL detection in the experimental Sardinian $\times$ Lacaune back-cross resource population will be exploited to implement marker or 
gene-assisted selection on such traits in the near future (Casu, 2004; Casu et al., 2004).

\section{Acknowledgements}

The authors wish to thank Severino Tolu and Salvatore Deiana for their committed effort in the care and maintenance of the animals and their excellent help with data collection.

\section{References}

Barillet, F., Arranz, J.J., Carta, A., Jacquiet, P., Stear, M., Bishop, S., 2006. Final consolidated report of the European Union contract of acronym "genesheepsafety" (QTLK5-CT-2000-00656), p. 145.

Barillet, F., 2007. Genetic improvement for dairy production in sheep and goats. Small Rumin. Res. 70, 60-75.

Bruckmaier, R.M., Blum, J.W., 1992. B-mode ultrasonography of mammary glands of cows, goats and sheep during alpha and beta adrenergic agonist and oxytocin administration. J. Dairy Res. 59, 151-159.

Bruckmaier, R.M., Paul, G., Mayer, G.P.H., Schams, D., 1997. Machine milking of Ostfriesian and Lacaune dairy sheep: udder anatomy, milk ejection and milk characteristics. J. Dairy Res. 64, 163-172.

Carta, A., Casu, S., Sanna, S.R., 2000. Preliminary analysis of kinetics of milk emission during machine milking in Sarda dairy sheep. In: Atti XIV Congr. Naz. SIPAOC, vol. 1, pp. 199-202.

Casu, S., 1967. La pecora Sarda e la mungitura meccanica. Riv. Zootecn. XL 23, 3-17.

Casu, S., Carta, R., Ruda, G., 1983. Morphologie de la mamelle et aptitude à la traite mécanique de la brebis sarde. In: Proceedings of the Third International Symposium on Machine Milking for Small Ruminants, Valladolid, Espana, pp. 592-602.

Casu, S., Deiana, S., Tolu, S., Carta, A., 2000. Linear evaluation of udder morphology in Sarda Dairy ewes: relationship with milk yield. In: Atti XIV Congr. Naz. SIPAOC, vol. 1, pp. 195-198.

Casu, S., 2004. Recherche de QTL contrôlant la cinétique de l'émission du lait et la morphologie de la mamelle chez les brebis laitières. Ph.D. Thesis. Institut national Agronomique Paris-Grignon, p. 292.

Casu, S., Robert-Granié, C., Barillet, F., Carta, A., Elsen, J.M., 2004. Identificazione di QTL che influenzano l'emissione del latte negli ovini. In: Proc XVI Nat. Congr. SIPAOC, p. 256.

Casu, S., Pernazza, I., Carta, A., 2006. Feasibility of a linear scoring method of udder morphology for the selection scheme of Sardinian sheep. J. Dairy Sci. 89, 2200-2209.

de la Fuente, L.F., Fernandez, G., San Primitivo, F., 1996. A linear evaluation system for udder traits of dairy ewes. Livest. Prod. Sci. 45, 171-178.

Fernandez, G., Baro, J.A., de la Fuente, L.F., San Primitivo, F., 1997. Genetic parameters for linear udder of dairy ewes. J. Dairy Sci. 80, 601-605.

Flamant, J.C., 1974. Estimation des paramètres génétiques du temps de trait, du débit moyenne, et des volumes de lait recueillis au cours des différentes phases de la traite des brebis. Symposium sur la traite mécanique des petits Ruminants, Millau, France, 7-11 mai 1973. Ann. Zootech., 158-161.

Gallego, L., Torres, A., Caja, G., Molina, M., Pilar, M., 1983. Fracciones de leche en el ordeno de oveja de raza manchega: quantification y evolution durante la lactacion. In: Proceedings of the Third International Symposium on Machine Milking of Small Ruminants, Valladolid, Spain, pp. 149-162.

Gilmour, A.R., Gogel, B.L., Cullis, B.R., Welham, S.J., Thompson, R., 2002. ASReml User Guide Release 1.0. VSN International Ltd., Hemel Hemstead, HP11ES, UK.

Guillouet, P., Ricard, E., Aurel, M.R., Jacquin, M., Astruc, J.M., Duval, P., Bibe, B., Barillet, F., 1990. Conception d'un système de contrôle laitier automatisé pour les ovins et caprins laitiers. In: Proceedings of the 27th Biennial Session of ICAR, Ottawa, Canada, EAAP pub. no. 50.

Ilahi, H., Manfredi, E., Chastin, P., Monod, F., Elsen, J.M., Le Roy, P., 2000. Genetic variability of milking speed of dairy goats. Genet. Res. 75, 315-319.

Labussière, J., 1969. Importance, composition et signification des différentes fractions de lait obtenues successivement au cours de la traite mécanique des brebis. Ann. Zootech. 18 (2), 185196.

Labussière, J., 1983. Etude des aptitudes laitières et de la facilité de traite de quelques races de brebis du bassin méditerranéen. In: Proceedings of the Third International Symposium on Machine Milking of Small Ruminants, Valladolid, Spain, pp. 730-803.

Labussière, J., 1988. Review of physiological and anatomical factors influencing the milking ability of ewes and the organisation of milking. Livest. Prod. Sci. 18, 253-274.

Labussière, J., Martinet, J., Denamur, R., 1969. The influence of the milk ejection reflex on the flow rate during the milking of ewes. J. Dairy Res. 36, 191-201.

Labussière, J., Ricordeau, G., 1970. Aptitude à la traite mécanique des brebis de race Préalpes du Sud et croisée Frisons $\times$ Préalpes: études à différents stades de la lactation. Ann. Zootech. 19 (2), 159-190.

Le Du, J., Benmederbel, B., 1984. Aptitude des chèvres Saanen à la traite mécanique. Relations avec les caractéristiques physiques du trayon. Ann. Zootech. 33, 375-384.

Le Du, J., de la Chevalerie, F.A., Taverna, M., Dano, Y., 1994. Aptitude des vaches à la traite mécanique: relations avec certaines caractéristiques physiques du trayon. Ann. Zootech. 43, 77-90.

Legarra, A., Ugarte, E., 2005. Genetic parameters of udder traits, somatic cell score, and milk yield in Latxa sheep. J. Dairy Sci. 88, 2238-2245.

Marie, C., Jacquin, M., Aurel, M.R., Pailler, F., Porte, D., Autran, P., Barillet, F., 1999. Déterminisme génétique de la cinétique d'émission du lait selon le potentiel laitier en race ovine Lacaune et relations phénotypiques avec la morphologie mammaire. In: Proceedings of the Sixth International Symposium on Milking of Small Ruminants, Athens, Greece, 26 September-1 October, 1998. EAAP Publication no. 95, pp. 381-388.

Marie-Etancelin, C., Casu S., Rupp, R., Carta, A., Barillet, F., 2001. New objectives of selection related to udder health, morphology and milkability in dairy sheep. In: Proceedings of the 52nd EAAP Annual Meeting, August 26-29, 2001, Budapest, Hungary. Abstract Book No. 7, p. 272.

Marie-Etancelin, C., Arhainx, J., Aurel, M.R., Autran, P., Bibé, B., Jacquin, M., Lagriffoul, G., Pailler, F., Porte, D., Ricard, E., Barillet, F., 2002. Estimates of genetic parameters for milk flow kinetics during machine milking in French Lacaune dairy sheep. In: Proceedings of the Seventh World Congress on Genetics Applied to Livestock Production, Montpellier, August 19-23, 2002. Com no. 01-51.

Marie-Etancelin, C., Casu, S., Aurel, M.R., Barillet, F., Carta, A., Deiana, S., Jacquin, M., Pailler, F., Porte, D., Tolu, S., 2003. New tools to appraise udder morphology and milkability in dairy sheep. Opt. Méd. AA-55, 71-80. 
Marie-Etancelin, C., Astruc, J.M., Porte, D., Larroque, H., RobertGranié, C., 2005. Multiple-trait genetic parameters and genetic evaluation of udder-type traits in Lacaune dairy ewes. Livest. Prod. Sci. 97, 211-218.

Marie-Etancelin, C., Manfredi, E., Aurel, M.R., Pailler, F., Arhainx, J., Ricard, E., Lagriffoul, G., Guillouet, P., Bibe, B., Barillet, F., 2006. Genetic analysis of milking ability in Lacaune dairy ewes. Genet. Sel. Evol. 38, 183-200.

Marnet, P.G., Combaud, J.F., Dano, Y., 1999. Relationships between characteristics of the teat and milkability in Lacaune ewes. In: Proceedings of the Sixth International Symposium on Milking of Small Ruminants, Athens, Greece, September 26-October 1, 1999. EAAP Publication no. 95, pp. 41-44.

McKusic, B.C., Thomas, D.L., Berger, Y.M., Marnet, P.G., 2002. Effect of milking interval on alveolar versus cisternal milk accumulation and milk production and composition in dairy ewes. J. Dairy Sci. 85, 2197-2206.

Ricard, E., Arhainx, J., Bouvier, F., Jacquin, M., Chastin, P., Astruc, J.M., Lagrifoul, G., Manfredi, E., Barillet, F., 1994. On farm test of INRA portable electronic jars for automatized milk recording of sheep and goat. In: Proceedings of the 29th Biennial Session of ICAR, Ottawa, Canada. EAAP pub. no. 75, pp. 47-51.

Ricordeau, G., Martinet, J., Denamur, R., 1963. Traite à la machine des brebis Préalpes du Sud. Importance des différentes opérations de la traite. Ann. Zootech. 12 (3), 203-225.
Ricordeau, G., Bouillon, J., Le Roy, P., Elsen, J.M., 1990. Déterminisme génétique du débit de lait au cours de la traite des chèvres. INRA Prod. Anim. 3 (2), 121-126.

Santus, E., Ghiroldi, S., 2005. Milkability genetic evaluation in Brown Swiss: An international approach. Interbull Bulletin 33. In: Proceedings of the 2005 Interbull Meeting, Uppsala, Sweden June 2-4, 2005, pp. 25-27.

SAS, 2000. SAS Online Doc CD, Version 8. SAS Institute Inc.

Serrano, M., Perez-Guzman, M.D., Monitoro, V., Jurado, J.J., 2002. Genetic analysis of udder traits in Manchega ewes. Livest. Prod. Sci. 77, 355-361.

Sprengel, D., Dodenhoff, J., Götz, K.-U., Duda, J., Dempfle, L., 2001. International genetic evaluation for Milkability. Interbull Bulletin 27. In: Proceedings of the 2001 Interbull Meeting, Budapest, Hungary, August 30-31, 2001, pp. 35-40.

Such, X., Caja, G., Pérez, L., 1999. Comparison of milking ability between Manchega and Lacaune dairy ewes. In: Proceedings of the Sixth International Symposium on the Milking of Small Ruminants, Athens, Greece, September 26-October 1, 1999. EAAP Publication no., pp. 45-50.

Weiss, D., Weinfurtner, M., Bruckmaier, R.M., 2004. Teat Anatomy and its relationship with quarter and udder milk flow characteristics in dairy cows. J. Dairy Sci. 87, 3280-3289. 